\title{
Salangid Fishes: Their past, present and future
}

TOSHIRO SARUWATARI, ${ }^{\prime}$ ICHIRO OOHARA, ${ }^{2}$ AND TAKANORI KOBAYASHI ${ }^{3}$

'Ocean Research Institute, University of Tokyo, 1-15-1 Minamidai, Nakano, Tokyo, 164-8639, Japan, ${ }^{2}$ National Research Institute of Fisheries Science, 2-12-4 Fukuura, Kanazawa, Yokohama, Kanagawa, 236-8648, Japan, ${ }^{3}$ National Research Institute of Aquaculture, 422-1Nakatsuhamaura, Nanseicho, Watarai-gun, Mie 516-0108, Japan.

SUMMARY: A review on the biology of Far East Teleost family Salangidae is presented, based on recent studies conducted by the authors during the past decade.

\section{KEY WORDS: Salangidae, Salmoniformes, molecular phylogeny, heterochrony, paedomorphism}

\section{INTRODUCTION}

The Japanese Archipelago is blessed with a rich and diversified fauna. One such example is the fishes of the family Salangidae, a family of Teleost endemic to the Far East. Currently, 4 genera and 11 species are recognized and 3 genera and 4 species inhabit Japan.1,2) This review describes the current research status of this unique group of Teleost, from systematics, molecular phylogeny, life history and conservation.

\section{General Biology}

Salangid fishes inhabit fresh, brackish and coastal waters of the Far East, from Vietnam to Sakhalin. ${ }^{1,2)}$ Most species spawn in spring, with some species spawning in autumn. Eggs are demersal and adhere to sand grains or other substrate matter with attaching filaments or attaching membrane.3) Basic biological parameters of Japanese Salanigid fishes are presented in Table 1. ${ }^{4-6)}$ Salangids feed primarily on zooplankton. Two characters make Salangid fishes unique among Teleosts: Sexual dimorphism and heterochrony. Secondary sexual characters appear in males. They are: 1) single row of scales at the base of anal fin, functioning as a suction cup to adhere to female body during courtship behavior; 2) Anal fin height is greater in males than in females, with fissure like structure on its surface; 3) First ray of pectoral fin longer and pointed in males; 4) Body height at anus greater in males than females. Heterochrony is discussed in detail later.

\section{Systematics}

The systematic position of Salangidae and the systematics of lower Euteleosts have attracted great deal of attention and interest amongst ichthyologists. Not only is this problem interesting as a pure object of science, but because of a moral and ethical issue this group has arose. ${ }^{7)}$ Johnson and Patterson ${ }^{8)}$ provides 
Table1. Basic Biological parameters of Japanese Salangid fishes.

\begin{tabular}{ccccc}
\hline \hline Species & Salangicthys & Salangichthys & Salanx & \multicolumn{2}{c}{ Neosalanx } \\
& microdon & ishikawae & ariakensis & regani \\
\hline Habitat & Brackish Water & Coastal Waters & Marine and Fresh & Fresh water \\
SL & $50-100 \mathrm{~mm}$ & $60 \mathrm{~mm}$ & $150 \mathrm{~mm}$ & $45 \mathrm{~mm}$ \\
Spawning Season & Spring & Spring & Autumn & Spring \\
Fecundity & $500-1000$ & 400 & Unknown & 450 \\
Egg Diameter & $0.65-0.98 \mathrm{~mm}$ & $0.96 \mathrm{~mm}$ & Unknown & $0.87 \mathrm{~mm}$ \\
Hatched larva & $3.9 \mathrm{~mm} \mathrm{NL}$ & $3.9 \mathrm{~mm} \mathrm{NL}$ & Unknown & $4.7 \mathrm{~mm} \mathrm{NL}$ \\
Diadromy & No & No & Anadromous? & No \\
\hline
\end{tabular}

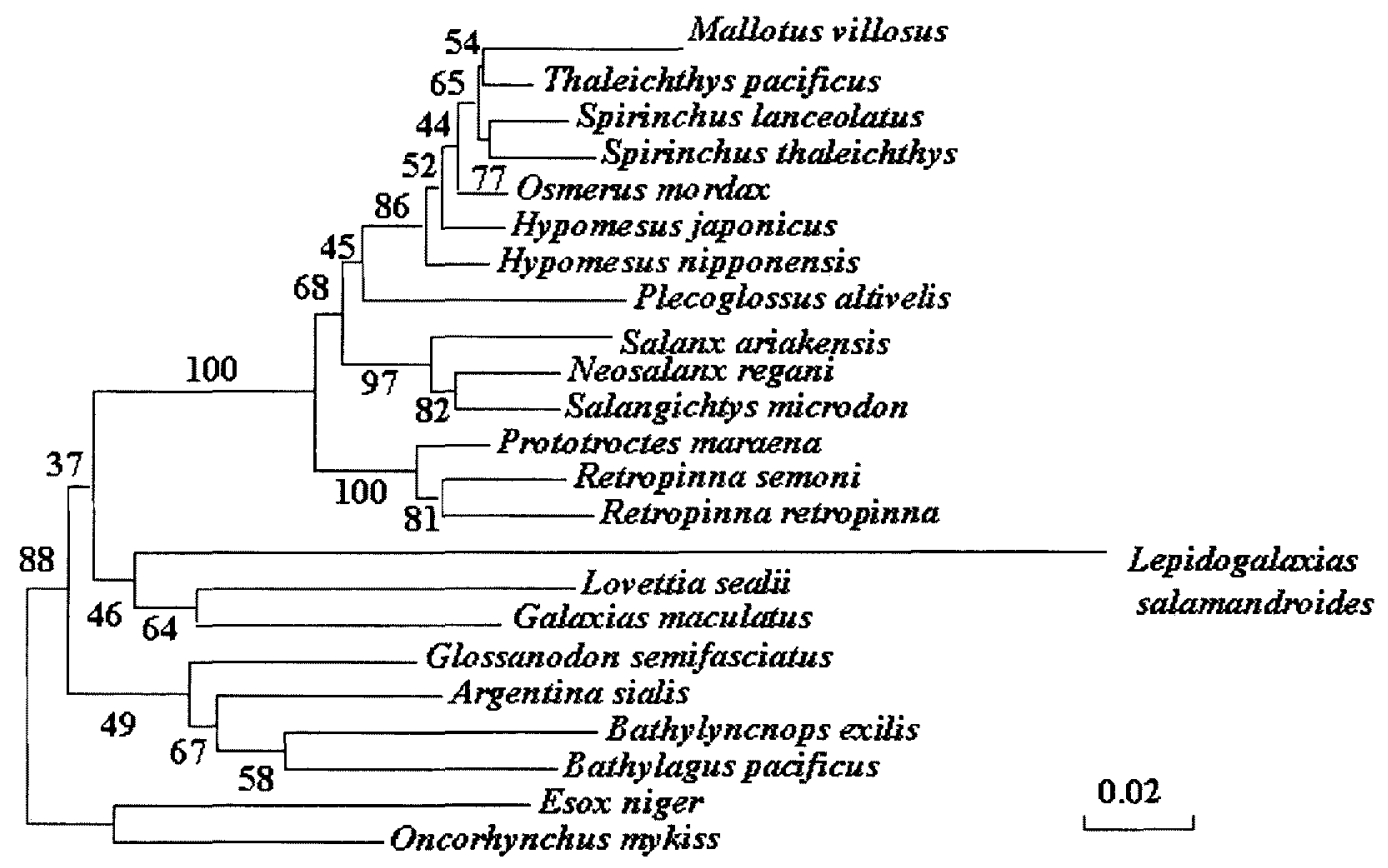

Figure 1.Molecualr phylogeny of Lower Euteleosts.

a good review of Salangidae and lower Euteleost region, the authors came up with first molecular phylogeny. All past studies were based primarily on phylogeny of the group. ${ }^{9)}$ The resultant tree morphological data, and molecular phylogeny of this indicates the Salangids to be the primitive sister group was long overdue. Using molecular sequence group of Osmeridae and Plecoglossidae. One obtained from 650 base pairs of 16SrRNA control interesting aspect of the tree is it places the 
southern hemisphere family Retropinnidae as the primitive sister groups of all northern hemisphere families, and apart from southern hemisphere families such as Galaxiidae, Aplochitonidae and Leidogalaxiidae with a very high bootstrap probability. This study clearly places Salangidae amongst the northern hemisphere clade, thus putting an end to the debate regarding its systematic position amongst Lower Euteleosts.

\section{Heterochrony}

Salangid fishes retain numerous larval characters at maturation and is regarded as Neotenic.2) However, because of the chaos in systematic of Salangids and its related taxa, detailed discussion on hetercochrony in Salangidae has not been made so far. The molecular tree of Lower Euteleosts provides strong phylogeny to discuss heterochrony observed in Salangids. Heterochronic characters found in Salangids when compared to its related sister families, Retropinnidae, Plecoglossidae and Osmeridae are: 1) lack of pigmentation on body; 2) lack of scales on body other than secondary sexual characters of males; 3 ) presence of larval finfold at maturation; 4) straight digestive tract; 5 ) half spherical otolith. All these characters are found commonly in Teleost larvae, and retention of such characters at maturation makes Salangidae a good example of paedomorphism in Teleosts. When ontogenies of Salangidae are compared with those of Plecoglossidae and Osmeridae, development is stopped at an earlier stage in Salangids. By adopting Reiley et al. ' $\mathrm{s}^{10)}$ model of heterochrony, this makes Salangidae to be paedomorphic through hypomorphosis.

\section{Adaptive significance of Paedomorphism in Salangids}

What caused paedomorphosis through hypomorphosis to evolve in Salangids? Clue can be found in their life histories. All Salangid fishes, whose life histories are known, are annual species, which live only for one year. In order to maintain a population, every yearclass must reproduce successfully every year. Female Gonadosomatic Index (GSI) of Salangichthys microdon is very high compared to related taxon (e.g. Hypomesus nipponensis and Pelcoglossus altivelis), over 20.6) A study on geographic variability on reproductive traits of $S$. microdon showed the presence of two types of reproductive tactics in the species: brackish lake type and river mouth type. The two tactics have different aims made possible through trade-off between fecundity (number of offspring) and egg diameter (quality of offspring). The brackish lake type's tactic aims at quantity of offspring against quality of offspring while the river mouth type's tactic aims at higher quality of offspring at the cost of its number. ${ }^{6)}$

High GSI and plasticity in reproductive strategy require very high energy output for reproduction. This is where paedomorphism through hypomorphosis comes into play. By arresting somatic development early in ontogeny, less or minimum energy is invested into somatic growth and development. This enables the 
individual to invest more surplus ingested energy into reproduction. Salangid fishes evolved a life history geared up for successful reproduction through paedomorphism, and is an extreme example of $r$-strategist amongst Teleosts.

\section{Conservation and future of Salangid fishes}

Of 3 genrea and 4 species of Japanese Salangid fishes, 2 species are listed as endangered by the Environmental Agency. Fifty \% of Japanese Salangid fishes are in the danger of extinction. Takita ${ }^{11)}$ noted drastic change in habitat of Neosalanx regani as a possible cause of its decrease. The basic life history trait of Salangid fishes, annual species, together with its habitat: fresh, brackish, and coastal waters, is a golden combination for extinction. After the Watergate was built at the mouth of Nagara River, population level of $S$. microdon, which once sustained a local fisheries of the species has dropped drastically. Human activities such as dredging of spawning ground during the specie's spawning season must be stopped. If we and the future generations appreciate Salangid fishes like Basyo did in his Haiku, immediate and effective measures must be taken to protect and preserve their habitats.

Dawn, Shirauo (S. microdon) so white, just an inch

Basho

\section{REFERENCES}

1. Wakiya Y, Takahashi N. Study on the fishes of the family
Salangidae. J. Coll. Agri., Tokyo Imp. U. 1937;14:265-304.

2. Roberts TR. Skeletal anatomy and classification of the neotenic Asian Salmoniform superfamily Salangoidea (Icefishes or Noodlefishes). Proc. Cal. Acad. Sci. 1984;43:179-220.

3. Senta T. Spawning ground of Shirauo in Takahashi River, Okayama Prefecgture. Jpn. J. Ichthyol. 1973;20:25-28. (in Japanese).

4. Saruwatari T. Studies on the reproductive biology of Japanese Salangid fishes. Doctorate dissertation presented to the faculty of Agrucultute, University of Tokyo. 1989.

5. Saruwatari T, Okiyama M. Life history of Shirauo Salangichthys microdon; Salangidae in a brackish lake, Lake Hinuma, Japan. Nippon Suisann Gakkaishi. 1992;58:235-248.

6. Saruwatari T. Shirauo, cunning wanderer of brackish waters. In: Goto A, Tsukamoto K, Maekawa K (eds). Freshwater fishes migrating between river and the sea-their life history and evolution-, Tokai University Press, Tokyo1994;74-85.

7. Patterson C. Johnson GD. Comments on Beglets "Monophyly and relationships of Argentinoid fishes". Copeia 1997;1997:401-409.

8. Johnson G D. Patterson C. Relationships of lower Euteleostean fishes. In: Stiassny, MLJ, Parenti LR, Johnson GD (eds). Interrelationships of fishes. Academic Press. 1996: 251-332.

9. Saruwatari T, Oohara I, Orr JW, McDowall RM, Kobayashi K. Phylogeny of lower Euteleosts reconstructed from mtDNA analysis. DNA Polymorphism 2000;8:96-101.

10. Reilly SM, Wiley EO, Meinhardt DJ. An integrative approach to heterochrony: the distinction between interspecific and intraspecific phenomena. Biol. J. Linn. Soc. 1997;60:119-143.

11. Takita T, Kawaguchi K, Masutani H. Ecology and distribution of Ariakehimeshirauo. Jpn. J. Ichthyol. 1988; 34:497-503. (in Japanese with English abstract) 